\title{
Problem Eksekutorial Putusan Hakim Pengadilan Tata Usaha Negara
}

\author{
F.A. Satria Putra \\ Fakultas Hukum, Universitas Islam Indonesia \\ E-Mail : Faisalsatria996@gmail.com
}

\begin{abstract}
Indonesia as a democratic country that has a system of state regulation that divides power into three, namely the legislature, executive, and judiciary to realize the principle of checks and balances. The form of control is owned by judicial institutions (judiciary) through judicial institutions that have the authority to provide legal certainty. The State Administrative Court as a judicial institution was formed based on Law No. 5 of 1986 to realize the state and national life system that is prosperous, safe, peaceful after order that can guarantee the position of citizens in law and become maintained a harmonious, balanced and harmonious relationship between the apparatus in the field of state administration and the citizens. This research uses normative legal research made with descriptive methods of analysis and using approaches qualitative. The implementation of the judicial process has systematic problems in the framework of the implementation of the judge's decision. In the case of the decision of the judges of the State Administrative Court, the problems that occur are the application of executions through the revocation of state administrative decisions (KTUN), the problem of execution through forced money, administrative sanctions, and the problem of delivering decisions posted on social media. The execution of the PTUN judge's decision is still experiencing various problems that occurred because the efforts to implement the verdict were handed over to TUN officials. Some of the problems that occur have not been regulated and have a definite legal umbrella.
\end{abstract}

Keywords : Authority PTUN, Judge's Verdict PTUN, Problematic execution.

\begin{abstract}
Abstrak
Indonesia sebagai negara demokratis yang memiliki sistem ketatanegaraan yang membagi kekuasaan menjadi tiga yaitu legislatif, eksekutif dan yudikatif guna mewujudkan prinsip check and balances. Bentuk kontrol yang dimiliki lembaga yudisial (kehakiman) melalui lembaga peradilan yang memiliki kewenangan memberikan pengayoman dan kepastian hukum. Pengadilan Tata Usaha Negara sebagai lembaga peradilan dibentuk berdasarkan Undang-undang Nomor 5 Tahun 1986 dengan tujuan mewujudkan tata kehidupan negara dan bangsa yang sejahtera, aman, tentram seta tertib yang dapat menjamin kedudukan warga masyarakat dalam hukum dan menjadi terpeliharanya hubungan serasi, seimbang serta selaras antara aparatur di bidang tata usaha Negara dengan para warga masyarakat. Penelitian ini menggunakan penelitian hukum normatif yang yang dibuat dengan metode deskriptif analisis dan menggunakan pendekatan kualitatif. Pelaksanaan proses peradilan memiliki problematika yang sistematis dalam rangka pelaksanaan putusan hakim. Dalam hal putusan hakim Pengadilan Tata Usaha Negara, Problematika yang terjadi yaitu penerapan eksekusi melalui pencabutan keputusan tata usaha Negara (KTUN), Problem eksekusi melalui uang paksa, sanksi administrasi dan problem penyampaian putusan yang diumumkan di media sosial. Eksekusi putusan hakim PTUN saat ini masih mengalami berbagai problematika
\end{abstract}


yang terjadi karena upaya pelaksanaan putusan diserahkan kepada pejabat TUN. Beberapa problematika yang terjadi belum diatur secara jelas dan memiliki payung hukum yang pasti.

Kata Kunci : Kewenangan PTUN, Putusan Hakim PTUN, Problematika eksekusi.

\section{PENDAHULUAN}

Sebagai Negara demokratis, Indonesia memiliki sistem ketatanegaraan yang membagi kekuasaan negara menjadi tiga lembaga, yaitu lembaga eksekutif, legislatif dan yudikatif. Ketiga lembaga tersebut memiliki keterkaitan dan saling kontrol guna memenuhi prinsip "check and balances". Peran kontrol yang dimiliki oleh lembaga yudisial (kehakiman) adalah melalui lembaga peradilan. Kaitan dengan kekuasaan kehakiman, Pasal 24 Ayat (2) Undang-Undang Dasar NRI 1945 menjelaskan bahwa "Penyelenggara kekuasaan kehakiman dilakukan oleh Mahkamah Agung dan badan peradilan yang berada di bawahnya dalam lingkup peradilan umum, lingkungan peradilan agama, lingkungan peradilan militer, lingkungan peradilan tata usaha negara, dan oleh sebuah Mahkamah Konstitusi.,

Selanjutnya dibentuk Peradilan Tata Usaha Negara yag diatur dalam Undang-undang Nomor 5 Tahun 1986 tentang Peradilan Tata Usaha Negara, yang kemudian direvisi menjadi Undangundang Nomor 9 Tahun 2004 tentang Perubahan atas Undang-undang Nomor 5 Tahun 1986 tentang Peradilan TUN. UU PTUN merupakan peraturan perundang-undangan yang mengatur tentang salah satu pelaksana kekuasaan peradilan bagi masyarakat yang mencari keadilan pada sengketa tata usaha Negara. Masyarakat yang mencari keadilan dimaksud adalah orang perorangan atau badan hukum perdata yang merasa kepentingannya dirugikan oleh Keputusan TUN (beschikking) sehingga mengajukan gugatan ke PTUN, yang berisi tentang tuntutan atas Keputusan TUN yang disengketakan, PTUN dapat membatalkan melalui suatu putusan yang telah berkekuatan hukum tetap.

Tujuan dibentuknya Peradilan Tata Usaha Negara adalah untuk mewujudkan perlindungan terhadap hak-hak perseorangan dan hak-hak masyarakat, secara serasi, seimbang, dan selaras antara kepentingan perseorangan dengan kepentingan masyarakat atau kepentingan umum. Menurut Sjachran Basah, Tujuan dibentuknya Peradilan Administrasi adalah untuk memberikan pengayoman hukum dan kepastian hukum, baik bagi rakyat maupun bagi administrasi Negara dalam arti terjaganya keseimbangan kepentingan masyarakat dengan kepentingan individu. Sedangkan Menurut S.F. Marbun tujuan Peradilan TUN adalah untuk mencegah tindakan 
administrasi Negara yang melawan hukum penjatuhan sanksi bagi pejabat negara yang merugikan masyarakat.

Dalam UU PTUN diatur mengenai objek sengketa yang diberikan wewenang penyelesaiannya pada PTUN, yaitu adalah Keputusan TUN (beschikking) yang terdapat pada pasal 1 ayat 3 yaitu "Keputusan Tata Usaha Negara adalah suatu penetapan tertulis yang dikeluarkan oleh badan atau pejabat Tata Usaha Negara yang berdasarkan peraturan perundang-undangan yang berlaku, yang bersifat kongkrit, individual dan final yang menimbulkan akibat hukum bagi seseorang atau badan hukum perdata”. Namun dalam UU No 30 Tahun 2014 tentang Administrasi Pemerintahan terdapat perluasan makna Keputusan TUN yaitu “a) Penetapan tertulis yang juga mencakup tindakan faktual; b) Keputusan badan dan/atau pejabat TUN di lingkungan eksekutif, legislatif, yudikatif dan penyelenggara negara lainnya; c) berdasarkan ketentuan perundang-undangan dan AAUPB; d) bersifat final dalam arti lebih luas; e) keputusan yang berpotensi menimbulkan akibat hukum; dan f) keputusan yang berlaku bagi warga masyarakat." Sedangkan PTUN berwenang menyelesaikan sengketa Keputusan TUN yang timbul dalam bidang Tata Usaha Negara antara orang atau badan hukum perdata dengan badan atau pejabat tata usaha negara, baik di pusat maupun di daerah, sebagai akibat dikeluarkannya keputusan tata usaha negara, termasuk sengketa kepegawaian berdasarkan peraturan perundangundangan.

Artinya bahwa setiap warga negara atau badan hukum yang bersengketa di PTUN mengharapkan adanya putusan yang memiliki kekuatan hukum tetap, sehingga ada penyelesaian yang diperoleh dari gugatan yang diberikan kepada pengadilan dalam eksekusi putusan tersebut. Masalah yang timbul dalam pelaksanaan putusan adalah sulitnya eksekusi terhadap putusan PTUN yang telah memiliki kekuatan hukum tetap. Berdasarkan pemaparan di atas, yang difokuskan pada penelitian ini adalah apa saja kompetensi PTUN dan muatan putusan hakim PTUN ? Apa saja problematika putusan hakim PTUN ?. Penelitian ini bertujuan untuk mengetahui dan menganalisis kewenangan pengadilan tata usaha negara dan problem eksekutorial putusan hakim pengadilan tata usaha Negara.

\section{METODE PENELITIAN}

Jenis metode penelitian yang digunakan adalah penelitian normatif. Pendekatan yang digunakan adalah pendekatan perundang-undangan (statue Aprroach) dalam level dogmatik hukum yang memfokuskan untuk mengkaji kaidah-kaidah dan norma-norma dalam peraturan 
perundang-undangan serta sumber hukum kepustakaan. Analisis data dilakukan dengan mengambil bahan hukum primer, sekunder dan tersier yang terkait dan diuraikan secara deskriptif analisis dengan metode penyajian kualitatif.

\section{PEMBAHASAN}

\section{Kompetensi Peradilan Tata Usaha Negara}

Peradilan Tata Usaha Negara (PTUN) merupakan institusi hukum yang seperti berada di tengah "keawaman" masyarakat. Sebagian besar masyarakat belum mengetahui PTUN sebagai sebuah pengadilan yang dapat memutuskan sebuah sengketa. Masyarakat belum banyak memahami PTUN memiliki kewenangan mengadili sengketa antara warga atau kelompok masyarakat dengan pemerintah akibat adanya Keputusan Pemerintah yang dianggap melanggar undang-undang atau asas-asas umum pemerintahan yang baik.

Kompetensi pengadilan dibedakan menjadi dua yaitu Pertama: Kompetensi relatif adalah kewenangan yang dimiliki lembaga peradilan yang mengatur tentang wilayah hukum yang mencakup wilayah kewenangannya. Pengadilan berwenang memeriksa suatu sengketa apabila salah satu pihak atau kedua belah pihak yang bersengketa berkediaman di wilayah hukumnya. Kompetensi relatif wilayah hukum Pengadilan Tata Usaha Negara dan Pengadilan Tinggi Tata Usaha Negara, dibedakan atas tiga daerah atau wilayah hukum, masing-masing meliputi wilayah kota madya atau kabupaten dan provinsi. dan Kedua : Kompetensi Absolute adalah kewenangan yang berhubungan dengan kewenangan PTUN memeriksa dan mengadili suatu sengketa menurut objek atau materi atau pokok sengketa. Meskipun badan/pejabat tata usaha negara dapat digugat di PTUN, tetapi tidak semua tindakannya dapat diadili. Tindakan badan/pejabat yang dapat digugat di PTUN yaitu hanya melalui sengketa Keputusan TUN (beschikking), bahkan untuk masalah pembuatan peraturan (regeling) yang dibuat oleh pemerintah yang bersifat umum, kewenangan untuk mengadili berada pada Mahkamah Agung melalui uji materiil. Kewenangan Absolute PTUN tidak hanya menangani Keputusan TUN saja, namun dalam hal suatu badan atau pejabat tata usaha negara tidak mengeluarkan suatu keputusan yang dimohonkan kepadanya, sedangkan hal itu adalah kewajiban.

Menurut Sjahran Basah, PTUN memiliki pembatasan dalam kewenangannya, yaitu Pembatasan langsung yang tidak memungkinkan sama sekali bagi PTUN untuk memeriksa dan memutus sengketa tersebut. 


\section{Putusan Hakim Pengadilan Tata Usaha Negara}

Putusan Hakim (vonnis) adalah suatu pernyataan oleh hakim sebagai pejabat negara yang diberi wewenang, diucapkan di persidangan dan bertujuan untuk menyelesaikan suatu perkara atau sengketa antar pihak. Putusan Pengadilan dibedakan atas dua macam, yaitu Pertama : putusan akhir (lind vonnis) Putusan Akhir (lind vonnis) adalah putusan yang sifatnya mengakhiri suatu sengketa. Putusan akhir adalah putusan yang bersifat hukum (condemnatoir), bersifat menciptakan (constitutif) dan bersifat menerangkan (declaratif). Kedua : Bukan putusan akhir (putusan sela/tussen vonnis/schorsing) adalah putusan oleh Hakim sebelum mengeluarkan putusan akhir dengan maksud mempermudah pemeriksaan perkara selanjutnya dalam rangka memberikan putusan akhir. Putusan sela dibedakan menjadi dua macam, yaitu putusan praeparatoir, misalnya putusan untuk menggabungkan dua perkara menjadi satu atau putusan untuk menetapkan tenggang waktu di mana para pihak harus bertindak. Putusan interlocutoir adalah putusan berisi perintah kepada salah satu pihak untuk membuktikan suatu hal.

Jika dicermati lebih dalam, pada Pasal 97 UU PTUN menjelaskan tentang Putusan yang lebih eksplisit, pada ayat (7) menjelaskan bahwa putusan pengadilan dapat berupa "a) gugatan ditolak; b) gugatan dikabulkan; c) gugatan tidak diterima; dan d) gugatan gugur." setelah dijatuhi putusan dan perkara dikabulkan, maka selanjutya diatur pada ayat (8) yaitu "Dalam hal gugatan dikabulkan, maka dalam putusan Pengadilan tersebut dapat ditetapkan kewajiban yang harus dilakukan oleh Badan atau Pejabat Tata Usaha Negara yang mengeluarkan Keputusan Tata Usaha Negara.” Keputusan Tata Usaha Negara yang harus dibuat diatur dalam ayat (9) yaitu “a) pencabutan Keputusan Tata Usaha Negara yang bersangkutan; atau b) pencabutan Keputusan Tata Usaha Negara yang bersangkutan dan menerbitkan Keputusan Tata Usaha Negara yang baru; atau c) penerbitan Keputusan Tata Usaha Negara."

Dalam penjelasan pasal 97 di atas detail tentang putusan, artinya bahwa putusan tersebut memuat apa yang harus dilakukan oleh badan atau pejabat tata usaha negara terhadap isi putusan sebagai langkah eksekutorial.

Isi putusan yang telah berkekuatan hukum tetap seharusnya menjadi dasar bagi pejabat atau lembaga tata usaha negara dalam melaksanakan keputusan yang telah menjadi "kewajiban" baginya. Namun dalam pelaksanaan putusannya ternyata masih terdapat beberapa problematika yang terjadi dan menimbulkan ketidakpastian hukum. 


\section{Problem Eksekutorial Putusan Hakim Pengadilan Tata Usaha Negara}

Pengadilan Tata Usaha Negara sebagai badan peradilan yang mempunyai kewenangan menghasilkan putusan yang memiliki kekuatan tergantung pada implementasi putusan tersebut. Proses eksekusi putusan menjadi tolak ukur sarana penting dalam penyelesaian sebuah sengketa. Eksekusi putusan merupakan realisasi dari tindakan atau kewajiban yang harus dilaksanakan oleh para pihak yang bersangkutan. Namun dalam pelaksanaan eksekusi masih terdapat problem yang terjadi atas ketidakpatuhan para pihak dalam melaksanakan eksekusi putusan pengadilan yang telah berkekuatan hukum tetap, terutama perihal sanksi yang diterima oleh pejabat negara yang tidak memiliki kesadaran untuk melaksanakannya. Beberapa problemnya ialah :

1. Problem penerapan eksekusi melalui Pencabutan Keputusan TUN.

Putusan Pengadilan TUN yang berisi kewajiban sebagaimana dimaksudkan dalam ketentuan Pasal 97 ayat (9) sub a, maka diterapkan eksekusi putusan menurut ketentuan Pasal 116 ayat (2) UU TUN, yaitu "empat bulan setelah putusan pengadilan yang telah memperoleh kekuatan hukum tetap sebagaimana dimaksud dalam Pasal 116 ayat (1) dikirimkan, tergugat tidak melaksanakan kewajibannya, maka KTUN yang bersangkutan tidak mempunyai kekuatan hukum lagi."

Berkaitan dengan eksekusi putusan menurut ketentuan Pasal 116 ayat (2) UU PTUN, maka permasalahan yang muncul kapan suatu KTUN yang dinyatakan tidak sah dan tidak mempunyai kekuatan mengikat lagi ? Apakah terhadap KTUN yang dinyatakan tidak sah tersebut harus memerlukan eksekusi ? Terhadap permasalahan tersebut dikaitkan dengan prinsip keabsahan tindakan pemerintah, dalam hal ini KTUN terkait dengan batas kepatuhan pejabat TUN kepada hukum, maka keputusan hukum yang tidak sah, dengan sendirinya tidak mempunyai kekuatan mengikat dan dengan demikian pula tidak perlu adanya eksekusi putusan, kecuali yang menyangkut kewajiban tertentu yang harus dilaksanakan sehubungan dengan dinyatakan tidak sahnya keputusan TUN. Cara eksekusi seperti ini disebut dengan "eksekusi otomatis".

Mengacu pada ketentuan Pasal 116 ayat (2) UU PTUN, dalam kaitannya dengan ketentuan Pasal 97 ayat (9) sub a UU PTUN, justru menimbulkan hambatan dalam praktik eksekusi putusan pada Pengadilan TUN itu sendiri maupun penggugat selaku pencari keadilan, hambatan itu dapat terjadi apabila putusan Pengadilan TUN telah berkekuatan hukum tetap, tetapi tergugat tidak mau mencabut keputusan TUN yang bersangkutan dengan 
mengambil sikap diam, tidak merealisasikan eksekusi putusan Pengadilan TUN sehubungan dengan amar putusan menurut ketentuan Pasal 97 ayat (9) sub a UU PTUN, maka menurut ketentuan Pasal 116 ayat (2) UU PTUN, harus menunggu empat bulan setelah keputusan TUN yang disengketakan itu tidak mempunyai kekuatan hukum lagi.

\section{Problem Eksekusi melalui Uang Paksa.}

Penerapan uang paksa dalam konsep hukum administrasi merupakan bagian dari sanksi administrasi yang dikenakan sebagai alternatif untuk paksa nyata (besturdwang) yang dilakukan organ atau pejabat pemerintahan dalam menjalankan fungsi pemerintahan. Pengenaan sanksi uang paksa pemerintah (dwangsom) dianggap sebagai putusan repatoir. Sanksi ini diterapkan jika warga negara melakukan pelanggaran. Dalam kaitannya dengan diterbitkannya Keputusan TUN yang menguntungkan, Pemohon izin diisyaratkan memberikan uang jaminan. Jika terjadi pelanggaran atau pelanggar tidak segera mengakhirinya, maka uang jaminan dipotong sebagai dwangsom. Organ pemerintah dalam menetapkan uang paksa, menentukan apakah uang paksa itu dibayar dengan cara mengangsur ataupun harus sekali bayar berdasarkan waktu tertentu. Organ pemerintah juga harus menetapkan jumlah maksimum uang paksa serta memperhatikan kesesuaian dengan beratnya kepentingan yang dilanggar dan harus sesuai dengan tujuan ditetapkannya penetapan uang paksa.

Dalam ketentuan pasal 116 ayat 4 UU PTUN yang berbunyi "Dalam hal tergugat tidak bersedia melaksanakan putusan pengadilan yang telah memperoleh kekuatan hukum tetap, terhadap pejabat yang bersangkutan dikenakan upaya paksa berupa pembayaran sejumlah uang paksa dan/atau sanksi administratif”'. terdapat karakter yuridis penerapan uang paksa sebagai akibat dipenuhinya putusan Pengadilan TUN. Eksekusi putusan ini melalui pembayaran sejumlah uang paksa lazim diterapkan dalam putusan yang dikenakan dalam lingkup peradilan umum (Perdata). Dalam putusan pengadilan memutuskan penghukuman terhadap yang kalah untuk suatu prestasi, maka dapatlah ditentukan dalamnya bahwa apabila yang terhukum tidak/belum memenuhi keputusan itu, yang sebagaimana disebut uang paksa. Dengan demikian uang paksa ini merupakan suatu alat eksekusi secara tidak langsung.

Permasalahan yang sering muncul dengan mekanisme pembayaran sejumlah uang paksa dalam hubungannya terhadap siapa uang paksa tersebut dibebankan ? Apakah pada keuangan instansi pejabat TUN yang bersangkutan atau kepada keuangan/harta pejabat TUN 
tersebut secara pribadi yang tidak melaksanakan putusan Peradilan TUN, dan berapa besar nominal yang harus dibayar?

Pembebanan uang paksa tersebut harus dibebankan kepada instansi atau badan dari pejabat TUN tersebut karena jabatannya. Namun faktanya pembayaran sejumlah uang paksa tidak menyelesaikan masalah substansial yang sebenarnya terjadi terhadap sengketa TUN. Karena sebagian besar penggugat menghendaki untuk adanya perubahan atas Keputusan TUN yang merugikan dirinya. Permasalahan tersebut terkait dengan penerapan sanksi pembayaran sejumlah uang paksa menyebabkan tidak berjalannya putusan pengadilan TUN karena tidak adanya peraturan pelaksanaan dalam menerapkan sanksi berupa uang paksa.

3. Eksekusi melalui Penerapan Sanksi Administrasi

Sanksi merupakan alat kekuasaan yang digunakan penguasa sebagai reaksi atas ketidakpatuhan terhadap norma hukum administrasi. Penerapan sanksi administrasi sebagaimana yang diatur dalam pasal 116 ayat (4) UU PTUN merupakan sanksi yang dikenakan oleh Pengadilan TUN sebagai pelaksana fungsi yudisial terhadap pejabat TUN sehubungan tidak patuhnya dengan Putusan Pengadilan TUN.

Dalam kaitannya penerapan sanksi administrasi terhadap pejabat TUN dalam kaitannya dengan pelaksanaan putusan pengadilan TUN yang tidak ditaati pejabat TUN, masih menimbulkan permasalahan siapa yang berwenang menerapkan sanksi, misalnya terhadap Presiden, Gubernur, Bupati, Walikota dan lainnya. Putusan hakim bersifat deklaratoir, sebatas menyatakan bahwa keputusan TUN yang disengketakan itu tidak sah atau batal. Kewenangan Pengadilan TUN hanya terbatas pada menetapkan sanksi administrasi apa yang akan dikenakan terhadap pejabat TUN. Namun dalam menjalankan penerapan sanksi administrasi yang memiliki kewenangan untuk melakukan adalah pejabat/organ pemerintahan melalui penerapan perundang-undangan.

\section{Diumumkan di Media Massa}

Dalam pasal 116 ayat (5) disebutkan bahwa "pejabat yang tidak melaksanakan putusan pengadilan maka diumumkan pada mesia massa cetak setempat oleh panitera." Sanksi ini bertujuan guna memberikan tekanan psikis kepada pejabat TUN yang tidak melaksanakan putusan yang telah berkekuatan hukum tetap. Dalam ketentuan tersebut tidak ada kejelasan tentang detail data pejabat yang diumumkan, seperti nama pejabat dan jabatannya. Karena dalam mengeluarkan Keputusan TUN pejabat tersebut bukan sebagai pribadi melainkan 
sebagai pejabat. Permasalahan lain yang kemungkinan timbul terkait pengumuman di media massa yaitu rentan dituduhnya sebagai pencemaran nama baik dan dimungkinkan untuk terjadinya pelaporan balik.

Berdasarkan tidak rincinya ketentuan tersebut dalam UU No 5 Tahun 1986 dan UU No 9 tahun 2004 tentang PTUN, maka seharusnya dilakukan revisi terhadap peraturan perundang-undangan tersebut atau ditindaklanjuti dengan peraturan pelaksanaan yang di dalamnya mengatur tentang pelaksanaan secara rinci sanksi tersebut.

Jika melihat problem di atas, Menurut Irfan Fachrudin, Problem yang terjadi pada pelaksanaan putusan peradilan TUN telah terjadi sejak peradilan TUN berdiri, hingga saat ini belum ditemukan mekanisme bagaimana eksekusi dilakukan sesuai dengan materi putusan. Artinya bahwa putusan hakim yang telah berkekuatan hukum tetap yang tidak dilaksanakan eksekusinya maka tidak bermanfaat dan tidak memiliki ketetapan hukum. Seyogianya putusan hakim adalah hukum atau undang-undang yang mengikat pihak yang bersengketa, karenanya para pihak seharusnya melaksanakan putusan tersebut dengan sukarela.

\section{SIMPULAN}

Peradilan Tata Usaha Negara memiliki kompetensi mengadili sengketa antara warga negara atau kelompok masyarakat dengan pemerintah akibat adanya Keputusan TUN (beschikking) sebagai hukum tertulis dan Asas-asas umum pemerintahan yang baik sebagai hukum tidak tertulis. Dalam melaksanakan fungsi peradilan, PTUN diberi wewenang untuk memberikan Putusan (Vonnis) untuk menyelesaikan sebuah perkara atau sengketa antara warga negara dan pemerintah.

Eksekusi putusan pengadilan TUN yang telah berkekuatan hukum tetap oleh pejabat TUN tidak sepenuhnya efektif, seperti eksekusi melalui pembayaran uang paksa, eksekusi putusan sanksi administrasi dan sampai pada pengumuman lewat media massa. Hal ini disebabkan karena tidak adanya kepastian pelaksanaan putusan pengadilan TUN yang tidak berjalan maksimal karena upaya eksekusi diserahkan sepenuhnya kepada pejabat TUN. Beberapa problem yang terjadi terhadap eksekusi Pengadilan TUN belum diatur secara jelas di dalam peraturan perundangundangan. Karenanya warga negara dan pejabat/organ pemerintahan banyak yang tidak mematuhi putusan tersebut. 


\section{DAFTAR PUSTAKA}

Irvan Mawardi, 2016, Paradigma Baru PTUN, Yogyakarta : Thafa Media.

Ismail Rumadan, 2012, Problematika Eksekusi Putusan Pengadilan Tata Usaha Negara, Jurnal Hukum dan Peradilan, Vol 1 No 3, DOI: http://dx.doi.org/10.25216/jhp.1.3.2012.435-462

Ivan Fauzani Raharja, 2014, Penenegakan Hukum Sanksi Administrasi, Jurnal Inovatif, Vol 7 No 2.

Nico Utama Handoko, 2020, Kekuatan Eksekutorial Putusan PTUN dan Implikasi Dalam Pelaksanaannya, Jurnal Pakuan Law Review, Vol 6 No 02, DOI : 10.33751/palar.v6i2.2140 R. Wiyono, 2009, Hukum Acara Peradilan Tata Usaha Negara, Cet 2, Jakarta : Sinar Grafika. Rechtreglement voor de Buitengewesten

Ridwan, dkk, 2018, Perluasan Kompetensi Absolute PTUN, Yogyakarta : Kreasi Total Media. , 2009, Tiga Dimensi Hukum Administrasi dan Peradilan Administrasi, Yogyakarta : FH UII Press.

S.F. Marbun, 2011, Peradilan Administrasi Negara dan Upaya Administrasi di Indonesia, Cet-3, Yogyakarta : FH UII Press. ,2018, Hukum Administrasi Negara I, Yogyakarta : FH UII Press.

Sjahran Basah, 1984, Eksistensi dan Tolok Ukur Badan Peradilan Administrasi di Indonesia, Bandung : Alumni.

Undang-undang Nomor 5 Tahun 1986 tentang Peradilan tata Usaha Negara

Undang-Undang Nomor 51 Tahun 2009 tentang Perubahan Kedua atas Undang-Undang Nomor 5

Tahun 1986 Tentang Peradilan Tata Usaha Negara

Yahya Harahap, 2009, Ruang Lingkup Permasalahan Eksekusi Bidang Perdata, Jakarta : Sinar Grafika. 